\title{
PERANCANGAN STRATEGIS DENGAN MEMANFAATKAN CMS WORDPRESS DAN FRAMEWORK ZACHMAN PADA LAMAN BERITA DI WEBSITE PEMERINTAH KABUPATEN MAGETAN
}

\author{
Ferdinand Wahyu Zulaiman Zaney ${ }^{1)}$, Hani Atun Mumtahana ${ }^{2)}$, Mei Lenawati ${ }^{3)}$ \\ ${ }^{1}$ Fakultas Teknik, Universitas PGRI Madiun \\ email: ferdinandferlanda@gmail.com \\ ${ }^{2}$ Fakultas Teknik, Universitas PGRI Madiun \\ email: hanimumtahana@unipma.ac.id \\ ${ }^{3}$ Fakultas Teknik, Universitas PGRI Madiun \\ email: mei.lenawati@unipma.ac.id
}

\begin{abstract}
Abstrak
Salah satu aplikasi yang berguna dalam pengoptimalan tampilan suatu website ialah CMS Wordpress. Pada website Pemerintah Kabupaten Magetan belum terdapat pilihan kategori berita, belum menampilkan gambar dalam list berita, urutan berita belum teratur, dan beberapa fitur lain yang belum memadai sehingga menu berita pada website Pemerintah Kabupaten Magetan belum optimal. Penelitian ini bertujuan mengetahui bagaimana mengevaluasi laman berita pada website Pemerintah Kabupaten Magetan serta bagaimana mengembangakan laman berita pada website Pemerintah Kabupaten Magetan dengan menggunakan Framework Zachman dan CMS Wordpress. Metode penelitian yang digunakan dalam perancangan strategis laman berita dengan memanfaatkan CMS Wordpress yaitu metode kualitatif. Metode tersebut untuk membuktikan kenyataanya dan mencapai tujuan penelitian yang bersifat objektif. Pada kesimpulan didapatkan bahwa rancangan telah sesuai dengan kebutuhan pengelola berdasarkan pada tahap evaluasi akhir, pemanfaatan Zachman Framework dan CMS Wordpress telah membantu peneliti dalam mengevaluasi laman berita berupa rancangan yang sesuai dengan kebutuhan pengelola, serta penggunaan CMS Wordpress pada pengembangan rancangan laman berita website pemerintah Kabupaten Magetan diharapkan dapat membantu masyarakat dalam mencari informasi dan berita yang ada di seputar kabupaten Magetan, juga dapat mempermudah pengelola untuk menerbitkan berita.
\end{abstract}

\section{Keywords: Maksimum Perancangan Strategis, Website, CMS Wordpress, Zachman Framework.}

\section{PENDAHULUAN}

Pemakaian website sebagai alat untuk menyampaikan berita merupakan salah satu bentuk pemanfaatan Teknologi Informasi dan Komunikasi. "Website adalah suatu media perangkat lunak yang terkoneksi dengan internet dan satu di antara manfaatnya yaitu untuk sarana menyampaikan informasi" [1]. Mudahnya proses penyampaian informasi melalui internet menyebabkan banyak pihak yang menyalahgunakan hal tersebut. Oleh karena itu, pemerintah menyediakan website berita resmi agar masyarakat dapat menemukan informasi yang dapat dipercaya.

Pada website Pemerintah Kabupaten Magetan memuat berita seputar informasi yang berkaitan dengan Kabupaten Magetan. Pihak Pemerintah Kabupaten Magetan bekerja sama dengan Dinas Komunikasi dan Jurnal Ilmiah "Technologia"
Informatika Kabupaten Magetan untuk mengelola website tersebut. Akan tetapi, tampilan pada menu berita dalam website Pemerintah Kabupaten Magetan belum optimal dan terkesan masih belum teratur. Berdasarkan hasil pengamatan, terdapat beberapa kekurangan dalam tampilan menu berita website Pemerintah Kabupaten Magetan, antara lain: (1) Tidak adanya pilihan kategori berita; (2) Gambar dalam list berita belum ditampilkan; (3) Urutan berita belum teratur; (4) dan lain sebagainya yang membuat menu berita pada website Pemerintah Kabupaten Magetan belum optimal. Hal ini menyebabkan turunnya tingkat kemudahan pengguna dalam mengakses website dan akan mengurangi penerimaan informasi yang didapat.

Adapun salah satu aplikasi yang digunakan untuk mengoptimalkan tampilan pada sebuah 
website yaitu CMS Wordpress. "Wordpress adalah salah satu media paling populer untuk membuat website baik berupa blog pribadi, situs perusahaan (company profile), situs pendidikan, bahkan situs komersil seperti toko online" [2]. Wordpress ini dikenal luas oleh blogger untuk memperindah tampilan blog mereka. Wordpress masuk dalam kategori CMS (Content Management System) karena wordpress dapat dimanfaatkan dalam mengubah atau edit tampilan pada suatu website. Content Management System (CMS) merupakan suatu aplikasi yang memberikan kemudahan kepada para penggunanya dalam mengelola dan mengadakan perubahan isi sebuah website [3].

Berdasarkan permasalahan di atas, maka pada penelitian ini akan dilakukan evaluasi dan perencanaan pengembangan guna memperbaiki tampilan, tata letak, dan struktur sistem laman berita pada website Pemerintah Kabupaten Magetan. Dalam membangun sebuah sistem informasi diperlukan perencanaan jangka panjang yang baik [8]. Pada penelitian ini akan digunakan Zachman Framework sebagai kerangka kerja yang dapat mengoptimalkan pengembangan arsitektur website dan CMS Wordpress sebagai aplikasi untuk merubah tampilan website. Zachman framework merupakan kerangka kerja yang diciptakan untuk mengetahui arsitektur perusahaan secara luas [4]. Berdasarkan pemaparan tersebut, dapat disimpulkan bahwa zachman framework adalah suatu kerangka kerja yang berguna untuk mengetahui seluruh arsitektur perusahaan agar dapat tersusun dengan baik. Selain itu, juga dapat digunakan untuk melakukan proses perancangan dalam mengembangkan sistem informasi berbasis enterprise system. Melalui penelitian ini diharapkan ke depannya dapat mempermudah Dinas Komunikasi dan Informatika Kabupaten Magetan untuk mengelola informasi pada laman berita dan juga memudahkan masyarakat untuk mengakses berita karena laman berita sudah mencapai user friendly.

Berdasarkan latar belakang tersebut perlu dilaksanakan penelitian yang berjudul "Perancangan Strategis Pemanfaatan CMS (Content Management System) Wordpress Pada Laman Berita Website Pemerintah Kabupaten Magetan Menggunakan Zachman Framework."

\section{METODE PENELITIAN}

Jurnal Ilmiah "Technologia"
Pada penelitian ini mempunyai rancangan penelitian yang berbentuk alur untuk memudahkan saat melakukan pemahaman pada penelitian. Gambar 1 merupakan rancangan penelitian dalam perancangan strategis laman berita website Pemerintah Kabupaten Magetan :

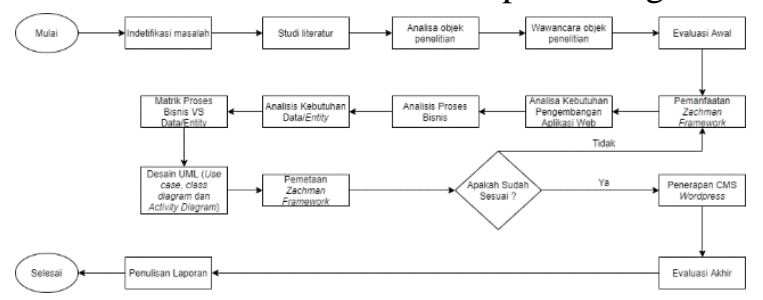

Gambar 1. Rancangan Penelitian

Berdasarkan rancnagan penelitian yang digambarkan pada Gambar 1, maka alur penelitian dapat dijelaskan sebagai berikut.

1. Mulai

Mulai dapat diartikan sebagai tahap awal dalam sebuah proses melakukan penelitian yang akan dilakukan.

2.

Identifikasi Masalah

Indetifikasi masalah merupakan proses dalam melakukan pengenalan terhadap masalah yang diangkat menjadi penelitian ini. Pada penelitian ini indetifikasi masalah dilakukan dengan cara melihat laman berita website Pemerintah Kabupaten Magetan serta menganalisis permasalahan yang ada di laman website tersebut.

3.

\section{Studi Literatur}

Studi literatur merupakan suatu tindakan untuk melakukan pencarian sebuah karya ilmiah seperti jurnal, artikel, buku, dan lain sebagainya yang berhubungan dengan permasalahan yang sedang diteliti.

4.

Analisis Objek Penelitian

Analisis terhadap objek penelitian merupakan kegiatan dalam mengamati proses yang terjadi pada objek yang diteliti dari segi luar yang dapat diketahui.

5.

Penelitian

Wawancara Terkait Objek

Wawancara ini bertujuan untuk mengetahui objek yang diteliti dari dalam khususnya proses bisnis yang terjadi pada objek tersebut. Wawancara juga dapat mengetahui kebutuhan dan permasalahan pada objek penelitian.

6.

Evaluasi Awal

Evaluasi awal bertujuan untuk mengorganisir kebutuhan maupun keinginan dari organisasi terkait laman berita ke depannya. 
Pada tahap ini peneliti memberikan kuesioner terkait kebutuhan dan keinginan pemilik.

7.

Pemanfaatan

Zachman

\section{Framework}

Pemanfaatan Zachman Framework dilakukan ketika sudah mengetahui permasalahan yang ada. Dari sini peneliti akan melakukan observasi terkait kebutuhan organisasi yang dapat memecahkan ataupun memperbaiki permasalahan pada laman berita website Pemerintah Kabupaten Magetan.

8 .

Penerapan CMS Wordpress

Penerapan CMS Wordpress berdasarkan pada hasil akhir dari pemanfaatan zachman framework, agar rekomendasi yang disampaikan peneliti sudah memenuhi kebutuhan organisasi maupun pengguna. Dalam tahap ini peneliti hanya membuat prototype saja.

9.

Evaluasi Akhir

Evaluasi akhir bertujuan agar peneliti dapat mengetahui bagian-bagian dari prototype yang harus dibenahi agar sesuai dengan kebutuhan organisasi. Untuk tahap ini peneliti memberikan kuesioner agar peneliti mengetahui bagian yang harus dievaluasi.

10.

Penulisan Laporan

Penulisan laporan merupakan salah satu bentuk dokumentasi penelitian dari awal hingga menghasilkan sebuah rancangan prototype sesuai kebutuhan organisasi dan pengguna.

11.

Selesai

Selesai dapat diartikan bahwa proses berakhirnya penelitian dan sebuah rancangan tadinya dapat dimanfaatkan organisasi ke depannya dalam pembenahan.

Untuk mendapatkan hasil yang diinginkan dan mengantisipasi adanya pembiasan masalah, maka dalam penelitian ini perlu diadakan pembatasan ruang lingkup sebagai berikut:

1.

Subjek penelitian ini terbatas pada halaman berita di website Pemerintah Kabupaten Magetan.

2.

Perubahaan yang nantinya menjadi rekomendasi dan akan disampaikan dalam objek penelitian menggunakan zachman framework yaitu pengembangan web laman berita menggunakan CMS wordpress dan didukung beberapa plugin yang disediakan wordpress, tema dari wordpress untuk memperindah tampilan laman berita, dapat diakses melalui smartphone maupun laptop di manapun kapanpun, memiliki login section admin dan pengguna agar membedakan hak admin sebagai pengelola maupun pengisi berita, dan hak pengguna sebagai komentator.

3. Zachman framework pada penelitian ini menggunakan 3 baris $\mathrm{x} 2$ kolom. Tiga baris tersebut yaitu Perencana, Pemilik, dan Perancang. Dua kolom tersebut yaitu meliputi What (Data) dan How (Function).

Tempat penelitian ini dilakukan di Dinas Komunikasi dan Informatika Kabupaten Magetan yang beralamat di JL. Kartini No. 2, Dusun Magetan, Kecamatan Magetan, Kabupaten Magetan, Jawa Timur. Adapun teknik pengumpulan data pada penelitian ini terdapat dua cara, antara lain sebagai berikut:

1.

Observasi

Observasi merupakan pengamatan langsung terhadap objek penelitian yaitu laman berita website Pemerintah Kabupaten Magetan guna mengetahui permasalahan yang ada dan juga mendapatkan data yang diperlukan dalam mengatasi permasalahan yang ada di laman berita website tersebut. Pengamatan yang dilakukan dapat memahami permasalahan secara jelas agar memperoleh data yang sangat akurat.

2.

Wawancara

Wawancara dilakukan secara langsung maupun tak langsung oleh pengelola laman berita website Pemerintah Kabupaten Magetan dan juga penggunanya dengan tujuan memperoleh informasi dan data secara nyata yang dibutuhkan dalam pengembangan sistem. Informasi dan data yang dibutuhkan antara lain keefektifan laman berita, kemudahan dalam mengakses, proses mengunggah berita, mengelola laman-laman berita, dan lain sebagainya yang berkaitan dalam aktivitas di laman berita website tersebut.

Kegiatan wawancara ini dilakukan agar pengembangan sistem nantinya telah sesuai dengan kebutuhan pengelola laman berita website dan juga pengguna yang mengakses laman berita.

Pada penelitian ini nantinya akan dijabarkan beberapa analisis. Analisis tersebut meliputi analisis proses bisnis dan analisis kebutuhan entitas. 


\section{HASIL DAN PEMBAHASAN}

Berikut ini adalah penjelasan terkait pemaparan hasil dan pembahasan dalam penelitian ini.

A. Laman Berita Website Pemerintah Kabupaten Magetan

Terdapat menu berita atau laman berita yang menyajikan berita dan informasi di dalam wilayah Kabupaten Magetan pada website resmi Pemerintah Kabupaten Magetan. Pemerintah Kabupaten Magetan bekerja sama dengan Dinas Komunikasi dan Informatika Kabupaten Magetan untuk mengelola website tersebut. Tujuan adanya laman berita di website Pemkab Magetan supaya masyarakat dapat dengan mudah memperoleh informasi yang beredar di Magetan serta mengenalkan masyarakat Magetan tentang website Pemkab Magetan yang berfungsi sebagai media yang menyebarkan informasi maupun berita di sekitar atau seputar Magetan. Akan tetapi, laman berita tersebut masih terdapat kekurangan di antaranya tampilan yang belum optimal dan terkesan tidak teratur. Ini dikarenakan berita yang ada di laman berita tersebut mengambil atau menautkan berita dari website Dinas Komunikasi dan Informatika Kabupaten Magetan. Hal itulah yang menyebabkan laman berita belum optimal sesuai dengan hasil kuesioner yang sebagian besar mengungkapkan bahwa tampilan terkesan kurang menarik atau user friendly. Sehingga mempengaruhi minat masyarakat untuk membaca berita di laman berita.

\section{B. Evaluasi Kebutuhan Pengembangan}

Pada tahap evaluasi kebutuhan dan pengembangan, peneliti melakukan observasi, wawancara, dan penyebaran kuesioner kepada pihak Kominfo khususnya di bidang Informasi dan Komunikasi Publik selaku pengelola laman berita di website Pemerintah Kabupaten Magetan. Kuesioner ditunjukkan kepada Seksi Pengelola Berita yang berjumlah 2 orang, dikarenakan seksi ini setiap harinya yang mengunggah berita ke dalam website. Tujuan dari pembuatan kuesioner tersebut adalah untuk mengetahui kebutuhan dan harapan pada laman berita nantinya. Dari hasil observasi, wawancara, dan penyebaran kuesioner tersebut pengelola sangat disarankan oleh pengguna yaitu masyarakat untuk melakukan pembenahan pada tampilan

Jurnal Ilmiah "Technologia" dan tata letak. Oleh karena itu, peneliti mengetahui bahwa perlu adanya pembenahan terhadap tampilan dan tata letak pada laman berita di website Pemerintah Kabupaten Magetan. Selain itu, peniliti juga mengetahui kebutuhan dari pihak Kominfo terkait laman berita yang nantinya dapat memenuhi visi dan misi Kominfo untuk menyebarluaskan informasi di Kabupaten Magetan serta menarik minat masyarakat untuk mengakses dan membaca informasi yang disajikan di laman berita tersebut.

C. Analisis Kebutuhan Pengembangan Aplikasi Web

\section{Analisis Kebutuhan Fungsional}

Berdasarkan hasil dari wawancara dan penyebaran kuesioner kepada pihak Kominfo, dapat diketahui kebutuhan fungsional yang diperlukan dalam pengembangan Laman Berita di website Pemerintah Kabupaten Magetan. Peneliti marangkumnya dalam sebuah tabel berikut ini.

Tabel 1. Kebutuhan Fungsional

No. Kebutuhan Fungsional

1. Perbaikan pada tampilan agar lebih optimal.

Sistem publikasi berita supaya

2. dapat dipisahkan dengan website Kominfo.

2. Analisis Kebutuhan Non-Fungsional

Berdasarkan hasil dari wawancara dan penyebaran kuesioner kepada pihak Kominfo, dapat diketahui kebutuhan non fungsional dalam pengembangan Laman Berita di website Pemerintah Kabupaten Magetan. Peneliti marangkumnya dalam sebuah tabel berikut ini.

Tabel 2. Kebutuhan Non-Fungsional

No. Kebutuhan Non-Fungsional

\begin{tabular}{cc}
\hline 1. & $\begin{array}{c}\text { Perbaikan pada tampilan agar } \\
\text { terlihat rapi dan nyaman dilihat }\end{array}$ \\
\hline 2. & $\begin{array}{c}\text { Mempermudah pengelola dalam } \\
\text { mempublikasi berita. }\end{array}$ \\
\hline 3. & $\begin{array}{c}\text { Memudahkan masyarakat dalam } \\
\text { membaca berita. }\end{array}$ \\
\hline
\end{tabular}

D. Analisis Proses Bisnis

Pada wawancara dengan pihak Kominfo, peneliti mengetahui proses bisnis yang terjadi di Bidang Informasi dan Komunikasi Publik. Pada bidang tersebut para tenaga kerja diberikan 
tanggung jawab untuk mencari, mengolah, dan menyebarkan informasi maupun berita yang terjadi di Kabupaten Magetan. Selain itu, para tenaga kerja diberikan tugas untuk memanfaatkan website Pemerintah Kabupaten Magetan sebagai media untuk mengedarkan seluruh informasi dan berita supaya Pemerintah Kabupaten Magetan transparan dalam melakukan segala hal. Berikut ini merupakan beberapa proses bisnis yang terjadi pada Kominfo di Bidang Informasi dan Komunikasi Publik.

\section{Proses Bisnis Mencari Berita}

Pada proses bisnis ini, Bidang Informasi dan Komunikasi Publik mencari berita yang beredar di masyarakat. Selain itu, berita harus lolos dari penilaian pimpinan agar berita dapat diolah dan diunggah.

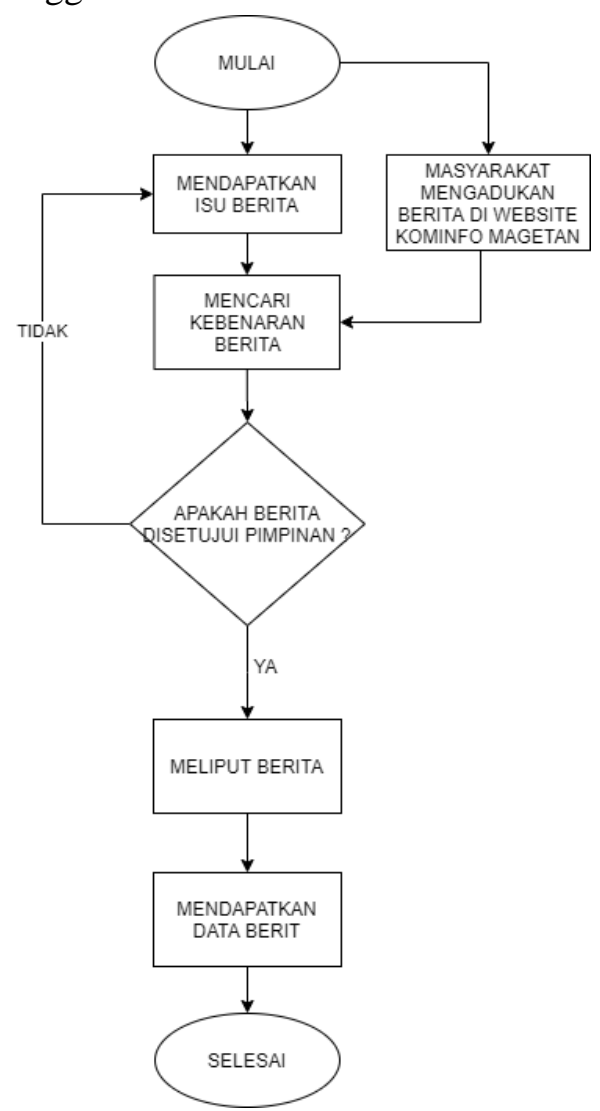

Gambar 2. Proses Bisnis Mencari Berita

\section{Proses Bisnis Mengolah Berita}

Setelah berita lolos penilaian pimpinan dan mendapatkan data berita selanjutnya, Bidang Informasi dan Komunikasi Publik mengolah berita agar menarik perhatian masyarakat ketika dipublikasi.

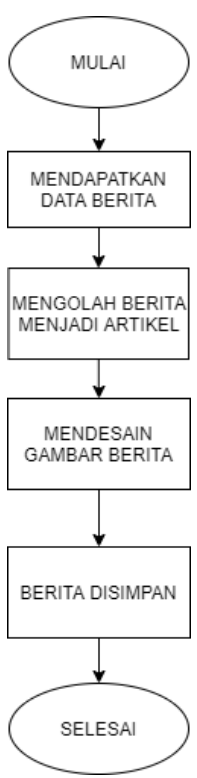

Gambar 3. Proses Bisnis Mengolah Berita

3. Proses Bisnis Mengunggah Berita

Jika berita sudah dipersiapkan untuk diunggah, maka Bidang Informasi dan Komunikasi Publik selaku pengelola melakukan pengunggahan berita yang telah siap dipublikasi kepada masyarakat.

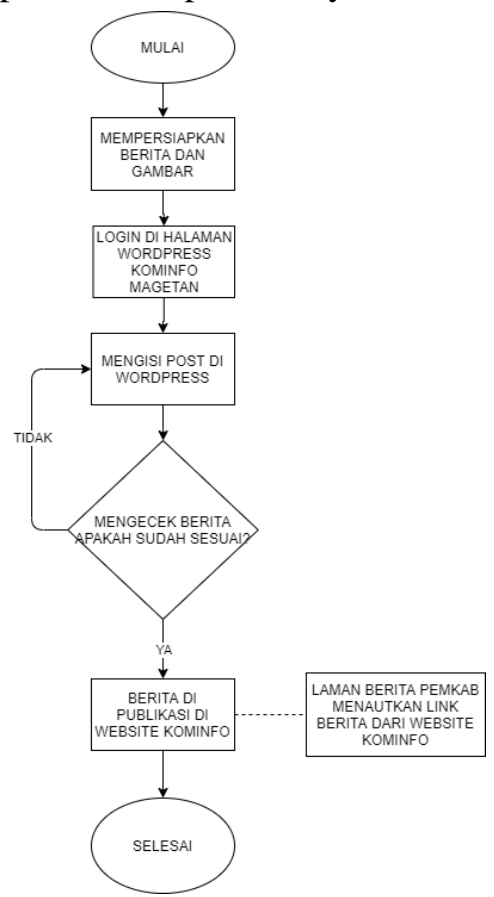

Gambar 4. Proses Bisnis Mengunggah Berita

E. Analisis Kebutuhan Entitas

Pada tahap ini, peneliti melakukan analisis terhadap kebutuhan entitas yang terjadi pada Bidang Informasi dan Komunikasi Publik Kominfo. Peneliti mengetahui kebutuhan entitas melalui wawancara. Kebutuhan entitas ini untuk menjalankan fungsi dan proses bisnis yang ada 
di Bidang Informasi dan Komunikasi Publik Kominfo. Oleh karena itu, peneliti membuat tabel kebutuhan entitas pada setiap proses bisnis sebagai berikut.

Tabel 3. Kebutuhan Entitas Pada Setiap Proses Bisnis

\begin{tabular}{cc}
\hline Proses Bisnis & Kebutuhan Entitas \\
\hline Mencari Berita & Data_Berita \\
\hline Mengolah Berita & $\begin{array}{c}\text { Data_pengelola } \\
\text { Data_Berita }\end{array}$ \\
\hline Mengunggah Berita & $\begin{array}{c}\text { Data_pengelola } \\
\text { Data_Berita } \\
\text { Data_pengguna }\end{array}$ \\
\hline
\end{tabular}

F. Matrik Proses Bisnis VS Data/Entity

Matrik proses bisnis vs data/entity bertujuan untuk keperluan pemenuhan tujuan fungsi bisnis. Matrik ini dibuat berdasarkan hubungan antara proses bisnis dengan data entitas. Peneliti membuat matrik proses bisnis vs data/entity berdasarkan analisis sebelumnya. Berikut ini disajikan tabel matrik proses bisnis vs data/entity laman berita website Pemkab Magetan.

Tabel 4. Matrik Proses Bisnis VS Data/Entity

\begin{tabular}{|c|c|c|c|}
\hline Entitas & 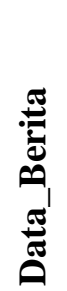 & 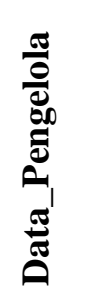 & 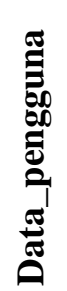 \\
\hline Mencari Data Berita & $\mathrm{C}$ & $\mathrm{C}$ & \\
\hline $\begin{array}{l}\text { Mengolah Data } \\
\text { Berita }\end{array}$ & & $\mathrm{CU}$ & \\
\hline Mempublikasi Berita & $\mathrm{CU}$ & CRU & $\mathrm{R}$ \\
\hline
\end{tabular}

G. Desain UML

Terkait Unified Modeling Language (UML) atau model bahasa yang nanti akan dijelaskan pada pemetaan zachman framework, terdapat 3 tipe diagram UML yang digunakan peneliti dalam penelitian ini antara lain:

\section{Use Case Diagram}

Use case diagram digunakan untuk menjelaskan tentang keterkaitan proses yang dilakukan entitas di dalam sistem. Peneliti menggunakan use case diagram untuk menjabarkan tentang kegiatan yang dilakukan entitas di dalam Laman Berita di website Pemkab Magetan. Berikut ini adalah gambar use case diagram dari
Laman Berita.

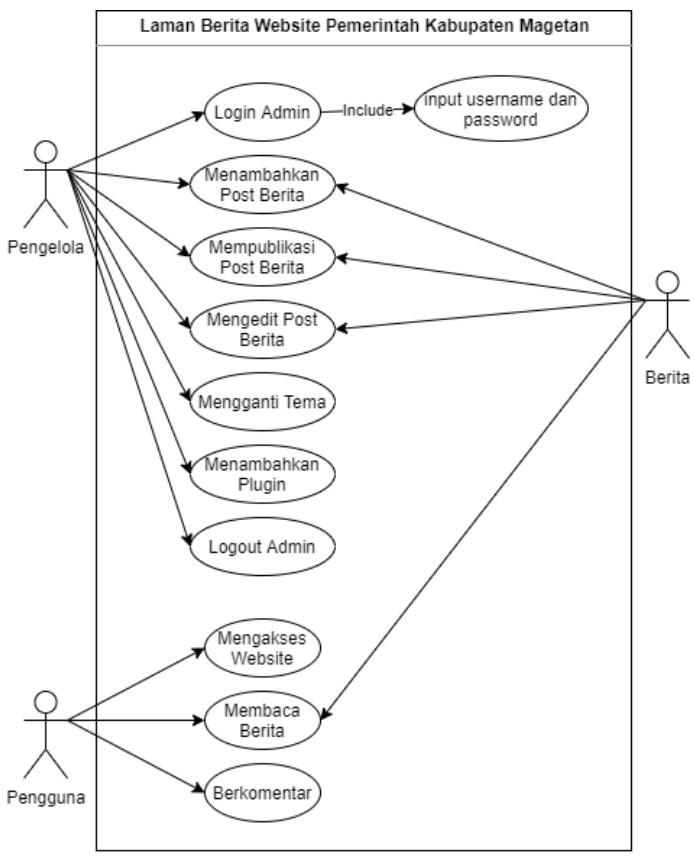

Gambar 5. Use Case Diagram di Laman Berita

\section{Class Diagram}

Pada class diagram menggambarkan struktur sistem dengan menunjukkan class, atribute, dan hubungan antar entitas. Pada laman berita Pemkab Magetan terdapat class diagram yang telah sesuai dengan use case diagram sebelumnya. Di bawah ini ialah gambaran dari class diagram di Laman Berita.

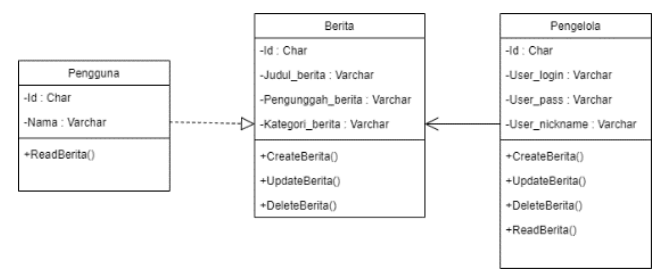

Gambar 6. Class Diagram di Laman Berita

\section{Activity Diagram}

Pada activity diagram dijelaskan tentang aktivitas dalam melakukan proses pengunggahan berita yang dilakukan oleh pengelola. Activity diagram digunakan untuk memberitahu pembuat program bagaimana alur pengelola di dalam Laman Berita. Di bawah ini merupakan activity diagram dari Laman Berita. 


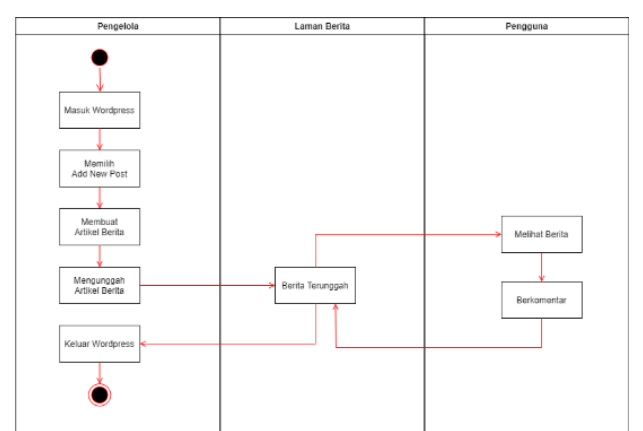

Gambar 6. Activity Diagram Laman Berita

H. Pemetaan Zachman Framework

Jika kebutuhan proses bisnis, proses data, dan matrik proses vs entitas telah diketahui, selanjutnya peneliti akan memetakannya menggunakan zachman framework supaya peneliti dapat dengan jelas dan mudah membuat rancangan pada Laman Berita. Pemetaan pada zachman framework sesuai dengan sudut pandang peneliti yang berupa baris dan kolom. Berikut ini Tabel 5 matrik zachman yang telah peneliti rangkai beserta dengan penjelasannya.

Tabel 5. Matrik Zachman Laman Berita Website Pemkab Magetan

\begin{tabular}{|c|c|c|}
\hline & $\begin{array}{l}\text { What } \\
\text { (Data) }\end{array}$ & $\begin{array}{c}\text { How } \\
\text { (Function })\end{array}$ \\
\hline $\begin{array}{c}\text { Contextual } \\
\text { (Perspektif } \\
\text { Perencana) }\end{array}$ & $\begin{array}{c}\text { Data } \\
\text { Berita, } \\
\text { Data } \\
\text { Pengelola } \\
\text {, dan } \\
\text { Data } \\
\text { Pengguna }\end{array}$ & $\begin{array}{c}\text { Proses } \\
\text { pengunggahan } \\
\text { berita dan } \\
\text { proses } \\
\text { pengaksesan } \\
\text { berita }\end{array}$ \\
\hline $\begin{array}{c}\text { Conceptual } \\
\text { (Perspektif } \\
\text { Pemilik) }\end{array}$ & $\begin{array}{l}\text { Daftar } \\
\text { Entitas }\end{array}$ & $\begin{array}{c}\text { Proses bisnis } \\
\text { yang } \\
\text { berhubungan } \\
\text { dengan } \\
\text { pengunggahan } \\
\text { berita dan } \\
\text { proses } \\
\text { pengaksesan } \\
\text { berita }\end{array}$ \\
\hline $\begin{array}{c}\text { Logical } \\
\text { (Perspektif } \\
\text { Perancang) }\end{array}$ & $\begin{array}{c}\text { Use case } \\
\text { dan Class } \\
\text { diagram }\end{array}$ & $\begin{array}{l}\text { Activity } \\
\text { diagram }\end{array}$ \\
\hline
\end{tabular}

1. Perspektif Perencana

Contextual merupakan nama lain dari perspektif perencana yang menjelaskan proses pengunggahan berita yang ada pada Laman Berita Pemkab Magetan.

a. What (Data): Yang dijelaskan pada kolom ini adalah data dari sudut pandang perencana. Hasil analisis data tersebut yaitu:

1. Data Berita ialah data berita Jurnal Ilmiah "Technologia" yang telah diperbolehkan untuk diunggah.

2. Data Pengelola merupakan data pengelola yang mengunggah berita ke Laman Berita.

3. Data Pengguna merupakan data pengguna yang mengakses berita ke Laman Berita.

b. How (Function): Yang dijelaskan pada kolom ini ialah tentang proses pengunggahan berita dan pengaksesan berita pada Laman Berita.

\section{Perspektif Pemilik}

Pada perspektif pemilik menjabarkan tentang sebuah sistem yang diusulkan oleh pemilik. Sistem tersebut nantinya berjalan dengan sistem yang telah ada sebelumnya.

a. What (Data): Yang dijelaskan pada kolom ini yaitu data dari sudut pandang pemilik. Hasil dari analisis berupa entitas yaitu:

1. Data_Berita ialah data berita yang telah diperbolehkan untuk diunggah.

2. Data_Pengelola merupakan data dari pengelola yang mengunggah berita ke Laman Berita.

3. Data_Pengguna merupakan data dari pengguna yang mengakses berita ke Laman Berita.

b. How (Function): Yang dijelaskan pada kolom ini adalah tentang proses pengunggahan berita dan pengaksesan berita dijelaskan dengan bentuk activity diagram.

\section{Perspektif Perancang}

Pada perspektif perancang yang akan menjadi dasar sebagai rancangan sistem dan tampilan yang berupa bahasa model. Bahasa model tersebut memperlihatkan tentang elemen data dan aliran proses fungsi pada rancangan sistem.

a. What (Data): Dalam kolom ini menggambarkan relasi entitas dengan proses yang dituangkan dalam bentuk use case dan class diagram.

b. How (Function): Pada kolom ini menggambarkan tentang aktivitas pengunggahan berita dan pengaksesan berita di Laman Berita yang berupa activity diagram. 
I.

$\mathrm{Pe}$

nerapan CMS Wordpress

Dalam menerapkan CMS Wordpress pada Laman Berita di website Pemerintah Kabupaten Magetan, peneliti telah mengetahui apa saja yang dibutuhkan oleh Bidang Informasi dan Komunikasi Publik Kominfo dengan melalui pengisian kuesioner yang telah peneliti berikan kepada beberapa anggota yang bertanggung jawab atas Laman Berita Pemkab Magetan. Hasil dari pengisian kuesioner tersebut maka peneliti merancang tampilan Laman Berita seperti yang dicontohkan di bawah ini.

\section{Tampilan Pengguna/Masyarakat}

Tampilan ini yang menjadi penghubung antara web dengan pengguna, agar nantinya pengguna dapat dengan mudah mempergunakan web. Ada beberapa fitur seperti Dark Mode yang dapat membantu pengguna membaca berita di malam hari.

a. Tampilan Sebelum Menggunakan CMS Wordpress

Pada tampilan sebelumnya, laman berita masih berupa judul berita yang tersusun secara vertikal dan belum memiliki gambar. Meskipun sudah memiliki fitur pencarian akan tetapi masih belum optimal sesuai tanggapan respondne pada kuesioner dan belum nyaman digunakan.

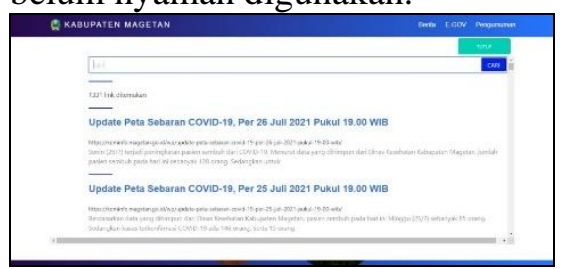

Gambar 7. Tampilan Laman Berita Sebelumnya

b. Tampilan Sesudah Menggunakan

CMS Wordpress

Penelitian ini menghasilkan sebuah rancangan untuk memperbaiki tampilan laman berita sebelumnya yang masih belum maksimal. Dengan bantuan CMS Wordpress peneliti dapat memaksimalkan tampilan agar user friendly serta membantu pengelola dalam mengolah website laman berita Pemkab Magetan.

1. Halaman Awal/Home

Jurnal Ilmiah "Technologia"
Halaman ini nantinya akan menjadi halaman utama dalam Laman Berita dan akan memuat beberapa Berita dan informasi. Penampilan Berita dan Informasi yang ada di halaman awal disesuaikan dengan kategori Berita maupun Berita yang sedang banyak diperbincangkan.

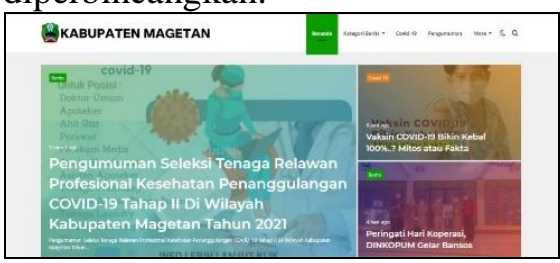

Gambar 8. Tampilan Atas Halaman Awal Laman Berita

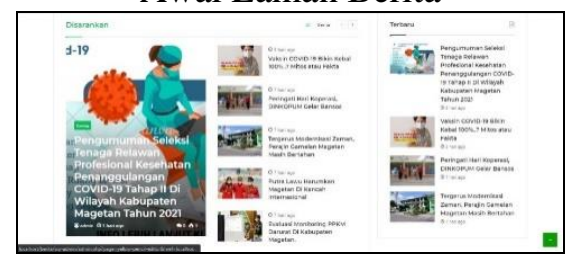

Gambar 9. Tampilan Tengah Halaman Awal Laman Berita

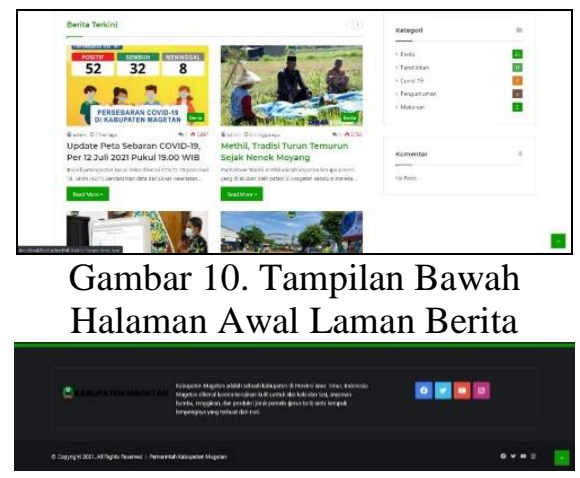

Gambar 11. Footer Semua Halaman 2. Mode Gelap

Fitur ini nantinya akan mempermudah dan membantu pengguna dalam membaca Berita pada malam hari yang minim cahaya. Penglihatan pengguna akan merasa nyaman jika menggunakan mode ini ketika malam hari.

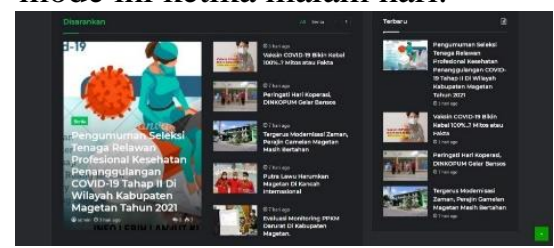

Gambar 11. Mode Gelap Laman Berita

3. Halaman Kategori Berita

Halaman ini nantinya akan menjadi halaman kategori beberapa berita dan model tata 
letaknya akan dibeda-bedakan sesuai kategori berita tersebut.

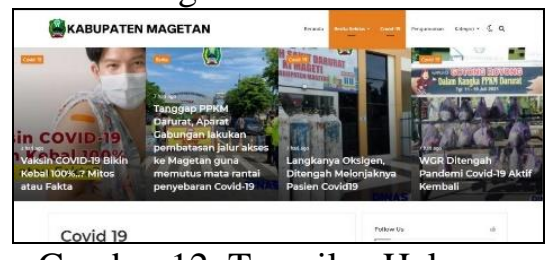

Gambar 12. Tampilan Halaman Kategori Covid 19

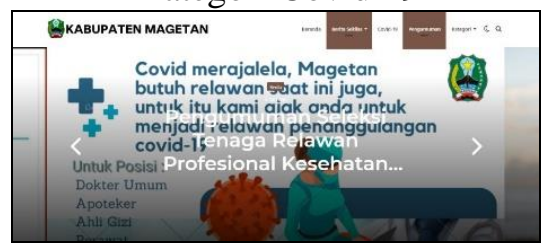

Gambar 13. Tampilan Halaman

Kategori Pengumuman

4. Halaman Berita

Halaman ini nantinya akan menjadi halaman tampilan berita dan informasi yang ada di Laman Berita. Tampilan dan tata letaknya berbeda disesuaikan dengan jenis berita.

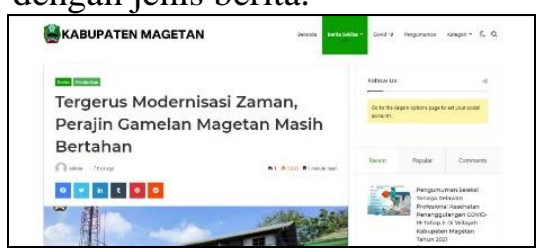

Gambar 14. Tampilan Halaman Berita Pendidikan

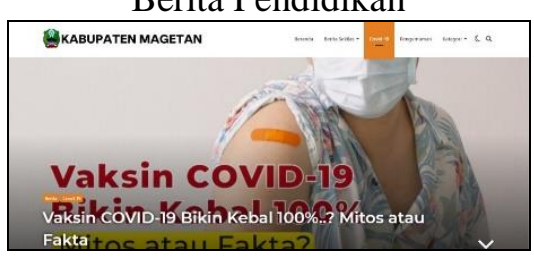

Gambar 15. Tampilan Halaman

Berita Covid

\section{Tampilan Pengelola}

Tampilan Pengelola merupakan tampilan yang hanya dapat diakses oleh pengelola untuk melakukan aktivitas hapus, edit, tambah di belakang tampilan pengguna. Pengelola dapat mengunggah berita, mengedit berita, menghapus berita, dan mengelola laman berita lainnya.

\section{a. Halaman Login}

Karena pada perancangan laman Berita ini menerapkan CMS Wordpress sebagai tampilan dan fungsinya. Maka, tampilannya berupa halaman login Wordpress.

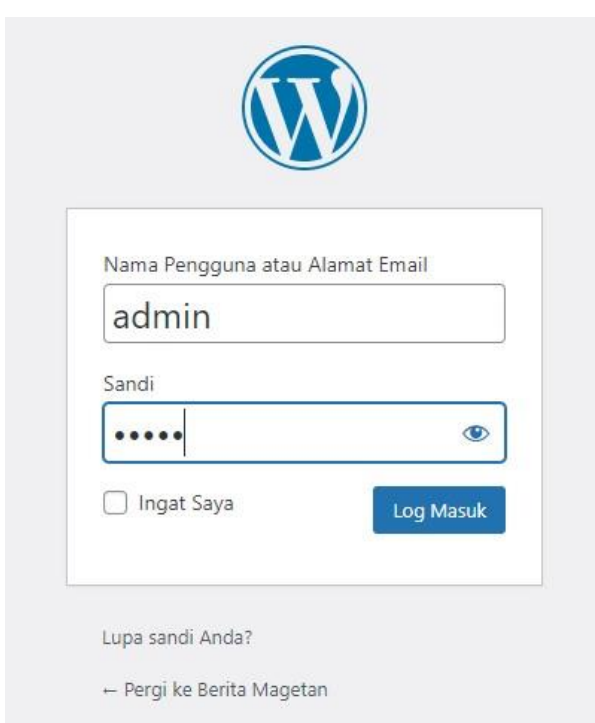

Gambar 16. Tampilan Halaman Login Pengelola Laman Berita

\section{b. Halaman Dasbor}

Halaman dasbor merupakan tampilan untuk pengelola saat awal login. Halaman ini hanyalah pengelola yang bisa mengakses dikarenakan dari sini pengelola memiliki kontrol penuh atas laman berita.

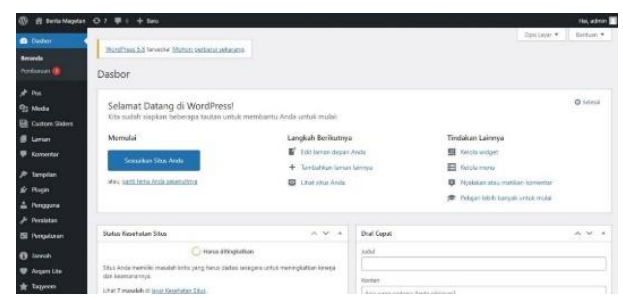

Gambar 17. Tampilan Halaman Dasbor Pengelola Laman Berita

\section{c. Halaman Post Berita}

Halaman ini menampilkan semua berita yang terdapat pada Laman Berita. Pengelola dapat menambahkan, mengedit maupun menghapus berita dari halaman ini.

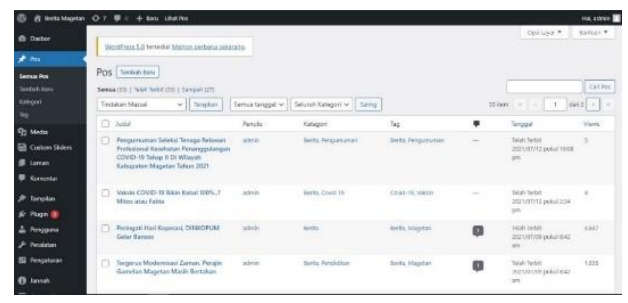

Gambar 18. Halaman Post berita Laman Berita

\section{d. Halaman Penulisan Berita}

Pengelola dapat mengunggah Berita melalui halaman ini. Banyak fitur yang tersedia untuk mengelola Berita agar Berita dapat menarik masyarakat untuk 
membacanya.

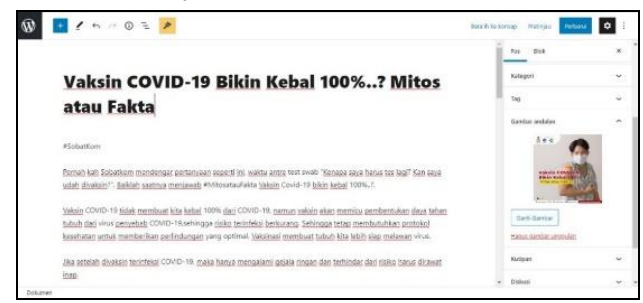

Gambar 19. Halaman Post Berita Laman Berita

\section{J. Evaluasi Akhir}

Dalam melakukan penilaian kebergunaan dan kesesuaian kebutuhan terhadap rancangan pada Laman Berita website Pemkab Magetan. Maka, peneliti melakukan evaluasi akhir terkait rancangan Laman Berita kepada Bidang Informasi dan Komunikasi Publik Kominfo selaku pengelola dengan memberikan kuesioner evaluasi perancangan. Poin-poin kuesioner evaluasi perancangan berdasarkan USE Questionnaire. "USE Questionnaire merupakan alat yang dapat digunakan dalam penyusunan pertanyaan-pertanyaan yang akan dibuat dalam bentuk kuesioner."'[5]. Tahap evaluasi ini dapat membantu peneliti dalam melakukan pembenahan yang lebih baik lagi ke depannya.

1. Daftar pertanyaan

Peneliti melakukan penilaian dengan membagikan kuesioner yang berjumlah 9 pertanyaan kepada Bidang Informasi dan Komunikasi Publik. Berikut ini merupakan pertanyaan yang diajukan kepada bidang Informasi dan Komunikasi Publik Kominfo.

Tabel 6. Daftar Pertanyaan

\begin{tabular}{|c|c|c|c|c|c|}
\hline \multirow{2}{*}{ No. } & \multirow{2}{*}{ Pertanyaan } & \multicolumn{4}{|c|}{ Skala Likert } \\
\hline & & STS & TS & $\mathbf{S}$ & SS \\
\hline 1. & $\begin{array}{l}\text { Laman Berita } \\
\text { yang terbaru } \\
\text { mudah } \\
\text { digunakan. }\end{array}$ & & & & \\
\hline 2. & $\begin{array}{l}\text { Laman Berita } \\
\text { yang terbaru } \\
\text { menjadi lebih } \\
\text { produktif. }\end{array}$ & & & & \\
\hline 3. & $\begin{array}{c}\text { Laman Berita } \\
\text { yang terbaru } \\
\text { menghemat } \\
\text { waktu saat anda } \\
\text { menggunakannya. }\end{array}$ & & & & \\
\hline 4. & $\begin{array}{c}\text { Laman Berita } \\
\text { yang terbaru } \\
\text { sangat sederhana. }\end{array}$ & & & & \\
\hline 5. & $\begin{array}{l}\text { Laman Berita } \\
\text { yang terbaru } \\
\text { sangat } u \text { ser }\end{array}$ & & & & \\
\hline
\end{tabular}

Jurnal Ilmiah “Technologia"

\begin{tabular}{cc}
\hline friendly \\
\hline Laman Berita \\
yang terbaru \\
mudah mengingat \\
bagaimana cara \\
menggunakannya
\end{tabular}

\section{Jawaban Pertanyaan}

Metode untuk menghitung nilai keseluruhan jawaban atas kuesioner evaluasi akhir terkait rancangan laman Berita yaitu menggunakan skala likert. "Untuk jawaban tidak puas Likert memberi skor dari yang paling kecil sampai yang paling besar yakni : jawaban sangat setuju (ST) diberi skor 4; yang setuju (S) diberi skor 3; tidak setuju (TS) diberi skor 2; dan sangat tidak setuju (STS) diberi skor 1." [6].

Kuesioner ini berhasil diisi oleh 4 respoden dari Bidang Informasi dan Komunkasi Publik Kominfo. Berikut hasil jawaban dari kuesioner yang telah di bagikan.

Tabel 7. Jawaban Pertanyaan

\begin{tabular}{|c|c|c|c|c|c|c|}
\hline \multirow{3}{*}{$\begin{array}{c}\text { Pertan } \\
\text {-yaan }\end{array}$} & \multicolumn{4}{|c|}{ Bobot } & \multirow{3}{*}{ Total } & \multirow{3}{*}{$\begin{array}{c}\begin{array}{c}\text { Prese } \\
\text { ntase }\end{array} \\
\text { (Total } \\
\text { /Nilai } \\
\text { Maksi } \\
\text { mum) } \\
* 100\end{array}$} \\
\hline & STS & $\begin{array}{l}\mathbf{T} \\
\mathbf{S}\end{array}$ & $\mathbf{S}$ & SS & & \\
\hline & 1 & 2 & 3 & 4 & & \\
\hline 1 & 0 & 0 & 9 & 4 & 13 & $81 \%$ \\
\hline 2 & 0 & 0 & 6 & 8 & 14 & $87 \%$ \\
\hline 3 & 0 & 0 & 9 & 4 & 13 & $81 \%$ \\
\hline 4 & 0 & 0 & 9 & 4 & 13 & $81 \%$ \\
\hline 5 & 0 & 0 & 3 & 12 & 15 & $93 \%$ \\
\hline 6 & 0 & 0 & 9 & 4 & 13 & $81 \%$ \\
\hline 7 & 0 & 0 & 6 & 8 & 14 & $87 \%$ \\
\hline 8 & 0 & 0 & 9 & 4 & 13 & $81 \%$ \\
\hline 9 & 0 & 0 & 9 & 4 & 13 & $81 \%$ \\
\hline & Rata-r & $\mathrm{Sk}$ & - & ian & & $83,6 \%$ \\
\hline
\end{tabular}

Berdasarkan hasil dari 4 responden Bidang Informasi dan Komunkasi Publik Kominfo didapat perhitungan sesuai perhitungan skala likert dengan nilai ratarata $83,6 \%$. Hasil tersebut termasuk dalam kategori sangat baik berdasarkan tabel 
klasifikasi nilai.

Tabel 8. Klasifikasi Nilai [7]

\begin{tabular}{cc}
\hline Angka \% & Klasifikasi \\
\hline$<25$ & Sangat tidak baik \\
\hline $26-50$ & Tidak baik \\
\hline $51-75$ & Baik \\
\hline $76-100$ & Sangat baik \\
\hline
\end{tabular}

\section{KESIMPULAN}

Berdasarkan penelitian yang telah dilaksanakan dalam analisa dan perancangan strategis laman berita website pemerintah kabupaten Magetan menggunakan CMS Wordpress ditemukan bahwa:

1. Rancangan tersebut sesuai dengan kebutuhan pengelola berdasarkan pada tahap evaluasi akhir. Pemanfaatan zachman framework dan CMS wordpress pada penelitian ini membantu peneliti dalam mengevaluasi Laman Berita berupa rancangan yang sesuai dengan kebutuhan pengelola. Penggunaan CMS wordpress pada pengembangan rancangan laman berita website Pemerintah Kabupaten Magetan diharapkan dapat membantu masyarakat dalam mencari informasi dan berita yang ada di seputar Kabupaten Magetan dan juga dapat mempermudah pengelola untuk menerbitkan berita.

Adapun saran dalam penelitian ini yakni guna memaksimalkan rancangan ini, diharapkan pengelola dapat meninjau ulang dan mengimplementasikan dengan semestinya agar menambah minat masyarakat Kabupaten Magetan dalam membaca berita di sekitarnya.

\section{REFERENSI}

[1]M. Faizal et al., "Penggunaan Website Portal Berita sebagai Media Informasi untuk Mahasiswa," J. Bhs. Rupa, vol. 2, no. 1, pp. 34-42, 2018.

[2]B. Badrudin and R. Nurdin, "SIM (Sistem Informasi Manajemen) Kurikulum Perguruan Tinggi Keagamaan Islam Berbasis CMS Wordpress," Ta'dib, vol. 22, no. 1, pp. 1-12, 2019.

[3]I. Risnaputra and G. Triyono, "PEMASANGAN E-COMMERCE BERBASIS CONTENT MANAGEMENT SYSTEM (CMS) WORDPRESS DENGAN METODE BUSINESS MODEL CANVAS (BMC) UNTUK PELAYANAN KATERING PADA CV. ALAM JAYA," IDEALIS Indones. J. Inf.
Syst., vol. 3, no. 1, pp. 481-485, 2020.

[4] M. A. Yaqin, F. A. A. Prayoga, A. N. Ihsan, and F. Pulungan, "Arsitektur Enterprise pada Permainan Hay Day Menggunakan Metode Zachman Framework," Pros. SENIATI, pp. 50-58, 2019.

[5]N. Asnawi, "Pengukuran usability aplikasi google classroom sebagai E-learning menggunakan USE questionnaire (studi kasus: Prodi Sistem Informasi UNIPMA)," Res. J. Comput. Inf. Syst. Technol. Manag., vol. 1, no. 1, pp. 17-21, 2018.

[6]R. H. Saputra, J. A. Baba, and G. Y. K. S. Siregar, "Penilaian Kinerja Dosen Menggunakan Modifikasi Skala Likert dengan Metode Simple Additive Weighting," Explore J. Sist. Inf. Dan Telematika Telekomun. Multimed. Dan Inform., vol. 9, no. 1, 2018.

[7]N. R. Riyadi, "Pengujian Usability Untuk Meningkatkan Antarmuka Aplikasi Mobile Myumm Students," Sist. J. Sist. Inf., vol. 8, no. 1, pp. 226-232, 2019.

[8] H. A. Mumtahana, W. W. Winarno, and A. Sunyoto, "Perancangan Master Plan Sistem Informasi Akademik STT Dharma Iswara Madiun," Khazanah Inform. J. Ilmu Komput. dan Inform., vol. 2, no. 2, p. 72, 2016, doi: 10.23917/khif.v2i2.2145.

Jurnal Ilmiah "Technologia" 